Прокопович, Лідія. «Функціонально-стилістичний аналіз афоризмів в романі Мирослава Дочинця „Мафтей”». Лінгвостилістичні студії, вип. 10, 2019, с. 154-162.

Prokopovych, Lidiia. "Functional and Stylistic Analysis of Aphorisms in the Novel "Maftei" by Myroslav Dochynets". Linguostylistic Studies, iss. 10, 2019, pp. 154-162.

УДК 82-84:821.161.2.31Дочинць7 Мафтей

https://doi.org/10.29038/2413-0923-2019-10-154-162

\title{
ФУНКЦІОНАЛЬНО-СТИЛІСТИЧНИЙ АНАЛІЗ АФОРИЗМІВ В РОМАНІ МИРОСЛАВА ДОЧИНЦЯ «МАФТЕЙ»
}

\author{
Лідія Прокопович \\ Мукачівський державний університет
}

У статті окреслено проблему становлення індивідуальних стилів на тлі загальнонаціональної мови. Розглянуто афоризми в романі Мирослава Дочинця «Мафтей», здійснено їх семантико-стилістичну класифікацію. Доведено особливості їх використання у художньому дискурсі та роль і місце в індивідуальній мовній картині письменника.

Ключові слова: ідіостиль, афоризми, сентенції, концепт, етносемантика.

Prokopovych Lidiia. Functional and Stylistic Analysis of Aphorisms in the Novel "Maftei" by Myroslav Dochynets. The problem of formation and development of the individual style of a writer is topical in modern linguistic studies. The writer's individual style in the context of the national language reflects the author's individual views and world perception through the peculiar language means or their unconventional use by the author. A detailed analysis of the views of scholars laid the foundation for studying the peculiarities of the individual style of the writer Myroslav Dochynets. Fiction works of Myroslav Dochynets have not yet been the subject of detailed linguistic studies (with the exception of A.Vegesh, L.Prokopovych, R.Terebus). However, the position of the author is obviously high in the modern literary world. Myroslav Dochynets is a winner of the highest awards in literature of Ukraine - the Taras Shevchenko National Prize in Literature, prestigious award of the President of Ukraine and many others.

One of the specific features of the writer's affluent language is the use of aphorisms. The aphorisms are the linguistic units that are not accidental in the content of the work but are necessarily subordinated to a definite plan of the author.

The article provides the functional and stylistic analysis of aphorisms. The emphasis is laid on the semantic and stylistic classification of the aphorisms, the peculiarities of their use in the artistic discourse, including their role and place in the linguistic picture of the world of the writer.

Aphorisms of Myroslav Dochynets constitute the semantic subsystem of his linguistic creativity. They excite by the depth and imagery, by the freshness of thought in the sentences concerning such themes as homeland and native home, about life, labor, world, love, happiness and destiny, about a woman. A significant group of aphorisms reflect philosophical ideas about the essence of life and human existence.

The article elucidates only certain aspects of the author's mastery of creating aphorisms. In the linguistic picture of a literary work, aphorisms are integral elements of the text and style creating units. This study does not comprise all issues of aphorism creation

(C) Прокопович Л., Східноєвропейський національний університет імені Лесі Українки, 2019.

Це стаття відкритого доступу на умовах CC BY-NC 4.0 
specificity of the prominent master of word. Further research of them is significant at the present stage of the linguistic studies development. discourse.

Key words: individual style, aphorisms, sentences, concept, ethnosemantics,

Вступ. Проблема становлення й формування індивідуального стилю письменника є однією з актуальних у сучасній лінгвостилістиці. Ідіостиль письменника репрезентує систему систем або систему особливої складності, оскільки категорія індивідуального стилю розглядається в контексті окремих характеристик. Унікальність кожної мовної особистості письменника визначені оригінальним добором етнічних, соціальних, ідеологічних, культурних, вікових та інших характеристик. «Письменник не просто вибирає мовні засоби, він мислить і переживає ними і тому здатен витворювати у своїй уяві і викликати в уяві читачів індивідуальні художні образи або їх відмінні риси. Ідіостиль письменника на тлі загальнонаціональної мови відображає його індивідуальне світобачення і світосприйняття через окремі специфічні мовні засоби чи оригінальне авторське використання їх» (Мацько 85).

Важливими при створенні власної картини світу $\epsilon$ особистий життєвий досвід, природні дані людини, інтелектуальний та духовний рівень. Письменник, створюючи картину, йде «шляхом пізнання й оцінки дійсності, що й формує його філософсько-естетичне кредо. Оцінювальний погляд автора організовує сюжет, він виявляється в композиції, в системі образів, у мові» (Сологуб 6).

Майстер слова, особливо художнього чи публіцистичного, намагається видобути 3 кожної мовленнєвої одиниці максимальний семантико- стилістичний ефект і разом з тим уміло використовувати його експресивну функцію. Лише тоді авторське висловлювання вражає своєю точністю та образністю, якщо вдається таке щасливе поєднання (а воно під силу лише видатним художникам слова), тоді можна говорити про індивідуальний стиль мовлення (ідіолект) - зауважує В. Жайворонок (28). «Стиль - це людина», - говорив Бюффон, і зв'язок між стилем, манерою мовлення та особистістю найтісніший. Чим колоритніша особистість, тим оригінальніший ï мовленнєвий стиль, оскільки внутрішні якості особистості неминуче виявляються в її мовленні.

Соціологічні чинники також позначаються на індивідуальному стилі: це стан літературної мови, і зокрема художнього мовлення, естетичної організації, мовна мода тощо. В певну епоху пишуть саме так й індивідуальні стилі дуже близькі, схожі, хоча кожен намагається виробити свій стиль художнього мовлення. Найталановитішим вдається прорвати коло загальноприйнятої обов'язковості та явити світу мистецтво свого слова (Мацько 186).

За останні роки проблема дослідження індивідуального стилю письменника була об'єктом зацікавлень багатьох науковців. Це дослідження 
С. Єрмоленко, В. Русанівського, Н. Сологуб, Л. Ставицької. Специфіку мовостилю закарпатського письменника Івана Чендея грунтовно дослідила В. Статєєва. Основна увага присвячена таким ознакам творчого доробку письменника, як лапідарність стилю, афористичність мови (Статєєва 288297). Л. Мацько, характеризуючи індивідуальний стиль Івана Драча, зауважує, що його індивідуальний стиль сповнений знаками сучасної інтелектуальної поезії і водночас закорінений у народнорозмовну фразеологію і побутивізм (86).

Детальний аналіз поглядів науковців став підгрунтям для дослідження особливостей індивідуального стилю письменника Мирослава Дочинця. Художні тексти Мирослава Дочинця ще не були предметом детальних мовознавчих студій (за винятком А.Вегеш, Л. Прокопович, Р. Теребуса), проте активно зміцнюють позиції автора як сучасного й успішного нагороди - лауреат найвищої нагороди в нашій державі - Національної премії України ім. Т. Шевченка, почесна відзнака Президента України, премія імені О. Духновича. Цей факт змушує задуматися над специфікою текстів та мовними засобами, що впливають на свідомість читача, роблять тексти не тільки змістовними, а ще й яскравими, зрозумілими та близькими читачеві. Про свою письменницьку роботу Мирослав Дочинець каже, що це дуже особистісний та інтимний процес: «Треба народитися на Закарпатті, щоб відчути пахощі, аромат нашої мови. Те, що закладене за словами» (Мирослав Дочинещь - прозаїк 7).

Одна із специфічних рис мовостилю письменника - афористичність мови. «Афоризм - це мудрість у портативній формі, концентрований екстрат думок і почуттів», - зазначає Вільям Рансвіл Олджер (Антологія 3).

Афористичність того чи того тексту грунтується на його структурноформальних і змістових ознаках. Йдеться про влучну, гостру думку, про судження, втілене в досконалій формі. Афоризми - це особливий комунікативно-прагматичний тип текстів (Радзієвська 12-13).

Поширення афористичних висловлювань залежить від умов функціонування літературної мови, її соціального престижу, узвичаєності в масовій культурі відповідних літературних текстів, від суголосності висловлення у цих текстах ідей, суджень громадській думці. Саме це зумовлює функціонування конкретної цитати і як частини цілісного авторського тексту, і як виокремленого з тексту самостійного судження, що має лаконічну форму і філософський узагальнений зміст (Єрмоленко, «Своєрідність» 152).

Оцінка такого змісту залежить, за словами О. Потебні, від «відношення мови до поезії й прози, тобто до літературної форми взагалі» (174). Розвиваючи думку про подібність між мовою, словом і художнім твором, наголосимо, що афоризм має самостійне життя як окремий твір. У ньому відбувається рух від внутрішньо текстового сприймання до комунікативної багатоплановості. Зміст художнього твору $є$ зумисною кореляцією того, що ми вибираємо, затримуємо, трансформуємо i, 
звичайно, побільшуємо у нашому сприйнятті (Фізер 67). У процесі естетичної аперцепції афоризм детермінується етнокультурним досвідом мовця (читача) (Єрмоленко, «Своєрідність»).

Мета дослідження - здійснити функціонально-стилістичний аналіз афоризмів в романі Мирослава Дочинця «Мафтей». Реалізація поставленої мети передбачає розв'язання таких завдань: виявити в тексті афоризми, здійснити семантико-стилістичну класифікацію, визначити особливості їх використання у художньому дискурсі та роль і місце в індивідуальній мовній картині письменника.

Матеріали і методи дослідження. Джерельною базою дослідження $\epsilon$ роман Мирослава Дочинця «Мафтей». Для розв'язання поставлених завдань у роботі використовуємо загальнонаукові та власне лінгвістичні методи: метод структурування (уможливив здійснити семантикостилістичну класифікацію афоризмів); метод функціональностилістичного аналізу (застосовано для з'ясування мовно-виражального, аксіологічного наповнення афоризмів).

Результати дослідження та дискусія. Зауважимо, що афоризми - це мовні одиниці, які не випадкові щодо змісту, вони обов'язково підпорядковані певному задуму. Вражають глибиною й образністю, свіжістю думки сентенції на теми про батьківщину і рідний дім, про життя, світ, працю, про любов, щастя і долю, про жінку. Значну групу становлять афоризми, які $\epsilon$ філософськими роздумами над сутністю життя, буття людини: $\epsilon$ смак життя - головний смак. Той смак, що в страві, у воді, в прилюбній роботі, в бесіді. Коли ти не їж те, в чому немає свіжого смаку. Не говориш довго з тим, хто мертвий душею. П'єш із чаші життя малими ковтками. Що можна ще просити від неба (Дочинець 74); Жити глибиною духа означає приймати свій триб цілісно (Дочинець 178); Життя, неборе, не ділиться на духовне і гріховне. Життя неподільне (Дочинець 196); ...життя жорстокіше за химери. Воно запліднюється протилежностями $i$ рухається протиріччями (Дочинець 337); Не кликати того, що минає дати йому відійти. Не чекати будучного - дозволити йому наступити, не ускладнювати насущного - хай станеться те, що має статися (Дочинець 249); Не те вражає, що засліплює. Не те провіщає, що голосно звучить. Нам не розгадати небесні глаголи. Зате нам відкриті прописи пережитого (Дочинець 102).

Із вербалізацією теми «буття людини» пов'язане функціональне навантаження іменника світ - «1. Сукупність усіх форм матерії як єдине ціле; всесвіт. 2. Окрема частина всесвіту. 3. Земна куля, Земля з усім, що на ній є» (Словник 9: 84). Ці значення формують своєрідний каркас для смислового й оцінного розростання номінації світ у процесі її метафоризації, мовно-естетичної трансформації у художньому дискурсі Мирослава Дочинця: Світ не переломиш. Подолати його чорноту можна лише створивши нову світлість (Дочинець 15); Кому легко на сериі, тому й весь світ сміється (Дочинець 72); Світ належить тим, хто йому радий. Ти 
заслуговуєш се. Бо, творячи свій світ, служиш людям, а отже й Господу (Дочинець 78); Овва, живий світ простіший, ніж наше уявлення про нього (Дочинець 295); Сам Бог прокидається, коли радість видить у світі (Дочинець 116); Світ належить радісним (Дочинець 116); Усе йде рукою. Риба чує добру руку, і тоді на долото ловиться. Такий закон світу: кому цвіте, кому в'яне... (Дочинець 126); Невидиме окові бачить жіноче серце, нечутне дорослому чує чутке дитяче вухо. Те, що не бачать жінки $i$ недочуває дитина, дознає юродивий, наділений пам'яттю крови. Бо вся колотнеча світу, все його злорадство паде в сум'ятну душу ізгоїв сього світу ... (Дочинець 36).

Афористичності висловлювання сприяють різноманітні форми повтору: лексичного, морфологічного, синтаксичного, а також лексикосемантичні відношення, що виявляються у лінійному, синтагматичному розгортанні тексту. Звертаємо увагу на контекстуальні антоніми: чорнотасвітлість. Синтаксичний паралелізм, фігури ампліфікації увиразнюють синонімічно близькі лексеми: радість, радісним, світлість, світ сміється. Одночасно виразну етносемантику, сакральні мотиви прочитуємо в сентенціях автора про життя, світ.

Опозиційним до життя є образ смерті. Він репрезентований через пряме називання цього стану людини: Бо смерть є смерть, і краси в ній шукати годі... (Дочинець 230); Біль усіх рівняє, а смерть примирює... (Дочинець 257).

Особливе емоційне напруження викликають сентенції, пов'язані 3 образом жінки, яка уособлює красу, найвищі моральні цінності: доброту, самовідданість, любов, працьовитість, милосердя, турботливість тощо. Легко купити жінку, малу й велику. Вони очима притягують нас. $A$ прив'язують волоссям. Не один заплутався в нім, як муха в тенетнику. Ой, не один. Тому косам жіноцтво годить більще, ніж лицю ... (Дочинець 35); Воістину лише жінка владна проявити нашу вкрадливу сутність. I коли мене питають, що вартий той чи інший чоловік, я з підсміхом кажу: придивися, яка жона за ним стоїть...( Дочинець 148); Дві найбільші тайни супроводять чоловіка. Се дорога до Бога і до жінки... (Дочинець 214); Цілком погоджуємося 3 думкою С. Єрмоленко, що авторські «характеристики, оформлені в образний вислів, часом переконують більше, ніж вибудовані за законами логіки, аргументовані докази» (Мацько 159).

Концептуально важливими для окреслення об'ємного психологічного образу людини в романі $\epsilon$ сентенції, створені 3 участю переважно позитивно маркованих номінацій та образів: праця, майстер, майстерність:Майстер - се той, хто знає правду і потрібен для життя (Дочинець 88); Що високо держиш, те й ціну має високу... (Дочинець 93); Правдивий митець відтворює не поверхню, а потайну сутність, яку ми приховуємо виразом; сміхом, словами і мовчанням... (Дочинець 224). 
Значна кількість афоризмів засвідчує стійкі морально-етичні та духовні переконання героїв роману: Праведник завжди каже правду, брехач завжди бреше. Се є непохитним правилом людської природи... (Дочинець 137); Бо де люди - там і колотнеча, там і силоміття. Рука руку дурить, око окові не довіряє... (Дочинець 259); Якою рукою подаш - такою дістанеш... (Дочинець 182); Останнім із того, що ми скидаємо перед кончиною, $\epsilon$ одіяння слави... (Дочинець 318); Геній продовжує жити, усе інше мертве... (Дочинець 319); ...стільки в нас ціни, скільки хочуть уподібнитися нам... (Дочинець 80).

Прислів'я - оказіоналізми, побудовані за дуже близькими до народних моделями: паралелізм, бінарна конструкція, метафоричність. Вони різняться ще однією особливістю: тут синтагми, смислові компоненти, - це окремі фразеологічні одиниці, що утворюють антитетичний або апліфікаційний паралелізм. Показовими у цьому випадку є поліфункційні одиниці про батьківщину, рідний дім: Місце, яке не покидаєш, яке прив'язує тебе - і є твоя в'язниця, тюрма з доброї волі... (Дочинець 16). Ні назвисько, ні кров, ні віра, не засягають приналежність до народности ... Дух, душа людини - ось що визначає якому народові вона припадає. Чим же се зміряти ? Проявленням духа - мислю. Хто на якій мові думає, той до такого народу належить (Дочинець 310); Свій берег - своя вода... (Дочинець 329); Ми надовго, на все життя спасенні світлими споминами з маленьства, скріплені добрами з нашого родительского дому (Дочинець 44); Знати можна лише єдно: куди б ти не йшов: вирушаєш із Дому і вертаєшся Додому... (Дочинець 309).

У семантичному мікрополі афоризмів про рідний край актуалізовано текстові зв'язки між висловами: місце... прив'язує тебе; дух, душа людини; свій берег - своя вода; спасенні світлими споминами з маленьства, скріплені добрами з нашого родительського дому.

Яскравий, емоційний колорит, мажорну настроєвість несуть афоризми, в основі яких лежать лексеми любов, щастя, надія, мрія: Надія вперта, вона родить на камені... (Дочинець 14); Файне і добре видіти - в сьому щастя $і є$ є... (Дочинець 186); Мудрій голові доста двох слів. $A$ люблячому серцю й того не треба... (Дочинець 71); ...Я з тим виріс і з тим живу: мова любови не потребує слів... (Дочинець 72); Історії любові пишуться на небі. Колись ми їх перечитаємо і побачимо весь свій путь... (Дочинець 79); Всяка жага сама себе споживає, а любов триває вічно... (Дочинець 347); Любимо не тих, з ким нам добре, а тих, без кого нам погано... (Дочинець 217); Якщо не маєш те, що любиш, полюби те, шо маєш... (Дочинець 80); Коли мрії стають сильнішими за страх, вони починають збуватися (Дочинець 243); Всі живуть потаємною мрією про крила...(Дочинець 29).

Афоризми, в основі яких лежать абстрактні поняття: безодня, зло, пиха , вада, багатство, несуть в собі навантаження оцінних характеристик. Це своєрідні авторські жести, які підкреслють негативну поведінку 
персонажа. Пор.: багатство: Багатство тільки сточує людей, але глибоко в них не проникає; всередині вони голі... (Дочинець 12); безодня: Зазираючи в безодню - притягуєш їі (Дочинець 22); зло: Зловмислення від мислення. Зла іскра все поле спалить і сама щезне (Дочинець 32); вада: Ваду вадою товчуть. На круте дерево крутий клин (Дочинець 133); пиха: Всяка задумана земна велич - та ж хвороба (Дочинець 134); Лісового звіра легко здобути, якщо змогти звіра в собі (Дочинець 232); Темні сили спокушають нас правдою, аби потім заплутати во лжі (Дочинець 267).

Письменник по-своєму дивиться на світ, по-своєму сприймає i розуміє його. Усі його думки, спогади перейшли в Слово і в Слові живуть. Слово він розуміє і сприймає як щось рідне і близьке. Тому і сентенції, пов'язані з образом думки, слова, глибокі, відбивають особливий стан душі, переживання, емоції: Слово, позбавлене любови, невиразне і марне (Дочинець 7); Пережите звіриться, як хмарина, а записане лишиться тестаментом твого серия (Дочинець 9); Нам не розгадати небесні глаголи. Зате нам відкриті прописи пережитого (Дочинець 102); Iз найцінніших дарів, не одержаних людиною від природи, а створених із власного духа, світ книг найбільший, а слово писемне священне (Дочинець 232); Думка постає не тільки в словах - вона і в мовчанні. 3 мовчанням зростають великі справи (Дочинець 244).

У романі Мирослава Дочинця релігійно-християнські лексеми часто актуалізують увесь семантичний набір традиційного ядра: 'очищення', 'незнищенність душі', 'терниста путь'. Відповідні лексичні одиниці входять до складу поліфункціональних: Бог занурює нас у глибокі води не для того, аби втопити, а щоби омити (Дочинець 37); Ми живі Його воскресінням. I в тому величному чуді немає ніяких нотацій, ніякого постраху чи заохоти. $\epsilon$ лише проста і страшна суть: смерть не мож подолати нічим, тільки смертю. Отсе і явив нам Ісус. Душа, не вбита гріхом, незнищенна. Тілесно ми смертні, а духом ніт. Єден ступ від життя до смерті. Зате який довгий $i$ тернистий путь від смерти до життя (Дочинець 327); ...моя отчизна $\epsilon$ книгою бога, мовою бога. I я невтоленно читаю їі (Дочинець 328); немає такого гріха, що переміг би милість Божу (Дочинець 196).

Висновки та перспективи дослідження. У результаті дослідження встановлено, що доступність, простота і водночас глибина суджень автора, залучення прикладів із власного життя - це ті риси його ідіостилю, що впливають на сприйняття й утвердження християнських цінностей. Максими Мирослава Дочинця становлять семантичну підсистему його мовної творчості. У цій підсистемі актуалізованими виявляються лексеми, пов'язані з концептами «батьківщина», «життя», «світ», «праця», «любов», «щастя», «доля», «жінка». Проаналізовані концепти - це водночас стильові ознаки мови української літератури початку XXI ст. У словесній картині художнього твору афоризми сприймаються як невід'ємні елементи тексту, стилетворчі одиниці. 
Перспективи наукових розвідок убачаємо в системному дослідженні семантики фразем в інших романах Мирослава Дочинця для визначення всієї системи афористичних одиниць в ідіостилі закарпатського письменника.

\section{Список використаної літератури}

Антологія афоризмів, упор. Л. П. Олексієнко. Донецьк, 2004.

Вегеш, Анастасія. «Промовистість назв романів М. Дочинця». Науковий вісник Ужгородського університету. Серія: Філологія. Соціальні комунікації, вип. 2 (32), 2014, c. 8-12.

Дочинець, Мирослав. Мафтей. Книга написана сухим пером. Мукачево: Карпатська вежа, 2016.

Жайворонок, Віталій. «Національна мова та ідіолект». Мовознавство, № 6, 1996, с. 2732.

Єрмоленко, Світлана. «Стиль індивідуальний». Українська мова: енциклопедія, за ред. В. М. Русанівського, і 0. О. Тараненка. Київ, 2000, с. 603-4.

Єрмоленко, Світлана. «Своєрідність художнього мовомислення Євгена Пашковського». Єрмоленко, Світлана. Мовно-естетичні знаки украӥнської культури. Київ: Інститут української мови НАН України, 2009.

Мацько, Любов. «Індивідуальний мовостиль Івана Драча». Філологічні науки: Збірник наукових праць. Суми: Сумський ДПУ ім. А. С. Макаренка, 2008, с. 85-92.

мирослав Дочинещь - прозаїк, філософ, публіщист. URL: http://miroslav-dochinets.com /?tmpl= unsupported.

Потебня, Александр. «Эстетика и поэтика». Мысль и язык. Москва, 1976.

Прокопович, Лідія. «Вербалізація концепту час у романі Мирослава Дочинця „Мафтей”». Науковий вісник Дрогобицького державного педагогічного університету імені Івана Франка. Серія «Філологічні науки». Мовознавство, № 8, т. 2, 2017, с. 66-9.

Радзієвська, Тетяна. Комунікативно-прагматичні аспекти текстотворення. Автореф. дис. ...докт. філол наук: 10.02.15. Київ, 1999.

Русанівський, Віталій. «Знайдене слово (Про мову творів Ю. Мушкетика)». Мовознавство, №4-5, 2000, с. 3-7.

Словник української мови, за ред. І. К. Білодіда. В 11 т. Київ: Наукова думка, 1970-1980.

Сологуб, Надія. Мовний світ Олеся Гончара. Київ: Наукова думка, 1991.

Ставицька, Леся. Естетика слова в художній літературі 20-30 рp. XX cm. (Системнофункціональний аспект). Автоеф. дис. ...докт. філол. наук: 10.02.01. Київ, 1996.

Статєєва, Валентина. «Специфіка мовостилю Івана Чендея». Лінговстилістика: Об'єкт стиль, мета - оцінка. Київ, 2007, с. 288-97.

Теребус, Роман. «Функціне навантаження власних назв у романах Мирослава Дочинця „Криничар” та „Вічник”. Науковий вісник Дрогобищького державного педагогічного університету імені Івана Франка. Серія «Філологічні науки». Мовознавство, № 8, т. 2, 2017, с. 110-3.

Фізер, Іван. Психолінгвістична теорія літератури Олександра Потебні: Метакритичне дослідження. Київ, 1996.

\section{References}

Antolohiia aforyzmiv, edited by L. P. Oleksiienko. Donetsk, 2004.

Vehesh, Anastasia. Expression of the Titles of the Novels by Myroslav Dochynets. Uzhhorod university scientific bulletin. Series "Philology. Social communications", iss. 2 (32), 2014, pp. 8-12.

Dochynets, Myroslav. Maftei. Knyha napysana sukhym perom. Mukachevo: Karpatska vezha, 2016. 
Zhaivoronok, Vitalii. "Natsionalna mova ta idiolect". Movoznavstvo, iss. 6, 1996, pp. 27-32.

Yermolenko, Svitlana. "Styl indyvidualnyi". Ukrainska mova: entsyklopediia, edited by V. M. Rusanivskyi, and 0. 0. Taranenko. Kyiv, 2000, pp. 603-4.

Yermolenko, Svitlana. "Svoieridnist khudozhnoho movomyslennia Yevhena Pashkovskoho". Yermolenko, Svitlana. Movno-estetychni znaky ukrainskoi kultury. Kyiv: Instytut ukrainskoi movy NAN Ukrainy, 2009.

Matsko, Liubov. «Indyvidualnyi movostyl Ivana Dracha». Filolohichni nauky: Zbirnyk naukovykh prats. Sumy: Sumskyi DPU im. A. S. Makarenka, 2008, pp. 85-92.

Myroslav Dochynets - prozaik, filosof, publitsyst. miroslav-dochinets.com /?tmpl= unsupported.

Potebnja, Aleksandr. "Jestetika i pojetika". Mysl' i jazyk. Moskva, 1976.

Prokopovych, Lidiia. "Verbalization of the Consept TIME in the novel "Maftey" by Miroslav Dochynets"'. Research Journal of Drohobych Ivan Franko State Pedagogical University. Series "Philology" (Linguistics), no 8, vol. 2, 2017, pp. 66-9.

Radziievska, Tetiana. Komunikatyvno-prahmatychni aspekty tekstotvorennia. Doctoral Thesis Abstract. Kyiv, 1999.

Rusanivskyi, Vitalii. “Znaidene slovo (Pro movu tvoriv Yu. Mushketyka)”. Movoznavstvo, no 45, 2000, pp. 3-7.

Slovnyk ukrainskoi movy, edited by I. K. Bilodid. 11 vols. Kyiv: Naukova dumka, 1970-1980.

Solohub, Nadiia. Movnyi svit Olesia Honchara. Kyiv: Naukova dumka, 1991.

Stavytska, Lesia. Estetyka slova v khudozhnii literaturi 20-30 rr. XX st. (Systemno-funktsionalnyi aspekt). Doctoral Thesis Abstract. Kyiv, 1996.

Statieieva, Valentyna. "Spetsyfika movostyliu Ivana Chendeia”. Linhovstylistyka: Obiekt - styl, meta - otsinka. Kyiv, 2007, pp. 288-97.

Terebus, Roman. Functional load of proper names in the novels "Krynychar" and "Vichnyk" by Myroslav Dochynets. Research Journal of Drohobych Ivan Franko State Pedagogical University. Series "Philology" (Linguistics), no 8, vols. 2, 2017, pp. 110-3.

Fizer, Ivan. Psykholinhvistychna teoriia literatury Oleksandra Potebni: Metakrytychne doslidzhennia. Kyiv, 1996. 